\title{
Su Samurlarında (Lutra lutra) Görülen Hastalıklar
}

\author{
Banur Boynukara' ${ }^{1}$ Timur Gülhan ${ }^{2}$ \\ ${ }^{1}$ Namık Kemal Üniversitesi, Veteriner Fakültesi, Mikrobiyoloji Anabilim Dalı, Tekirdağ \\ ${ }^{2}$ Ondokuz Mayls Üniversitesi, Veteriner Fakültesi, Mikrobiyoloji Anabilim Dall, Samsun
}

Geliş Tarihi / Received: 25.02.2016, Kabul Tarihi / Accepted: 03.05.2016

\begin{abstract}
Özet: Su samuru (Lutra lutra) yarı-sucul yaşayan, etçiller takımının sansargiller familyasında yer alan avcı bir hayvandır. Ekolojik dengenin göstergesi konumundaki bu hayvanlar dünyanın pek çok ülkesinde olduğu gibi ülkemizde de nesli tükenme noktasına geldiği için koruma altına alınmıştır. Su samurlarının mikrobiyal florası çok değişkenlik göstermesine rağmen, viral, bakteriyel, mantar ve paraziter hastalıklardan etkilenebilmektedirler. Pek çok evcil ve yabani hayvan türünde olduğu gibi insan populasyonları ile zaman zaman temas halinde oldukları için, özellikle taşıdıkları zoonoz etkenler açısından bu hayvanlarda görülen hastalıkların detaylı olarak incelenmesi önem arz etmektedir.
\end{abstract}

Anahtar kelimeler: Hastalık, Su samuru (Lutra lutra)

\section{Diseases in Otters (Lutra lutra)}

\begin{abstract}
The otter (Lutra lutra) is a hunter animal living a semi-aquatic in located Mustalidae family of carnivorous order. Indicator positions in the ecological balance of these animals as well as in many countries of the world in our country are also protected because it came to the point of extinction. Although the microbial flora of the otters much variability, they may be affected from viral, bacterial, fungal and parasitic diseases. It is important detailed examination of diseases in these animals, especially in terms of zoonotic agents; because of they are sometimes in contact with human populations as well as many domestic and wild animals.
\end{abstract}

Key words: Disease, Otter (Lutra lutra)

\section{Giriş}

Türkiye'de bilinen 160 memeli türü vardır. Bunların yaklaşı1 120'si yasalar kapsamında koruma altına alınmış ve 11'i de belirli dönemlerde avına izin verilen yaban hayvanları arasında yer almaktadır. Ülkemizdeki memeli hayvan türü sayısı pek çok Avrupa ülkesinden daha fazladır. Ancak ekosistemdeki olumsuz gelişmeler nedeniyle bazı türlerin nesilleri tükenme noktasına gelmiştir. Nesli tükenme noktasina gelen memeli türlerinden bir tanesi de su samuru (Lutra lutra Linnaeus, 1758)'dur [28].

$\mathrm{Su}$ samurları, etçiller (Carnivora) takımında, sansargiller (Mustelidea) familyasında, yer alan yar1-sucul avc1 hayvanlardır. Lutra lutra'nın bilinen on alt türü bildirilmektedir (Tablo 1). Ayrıca, kesin olarak bilinmeyen Angustifrons, Roensis, Splendida, Stejnegeri olmak üzere 4 alt tür daha tanımlanmiştır [21].

Sucul ekosistemin en üst basamağında yer alan, biyolojik çeşitliliğin ve ekolojik-dengenin bir göstergesi olan bu hayvanlar, dünya çapında tehli- ke altında olan diğer hayvanlar gibi kırmızı listede (IUCN/WCMC Red Data List) yer almaktadır [25]. Su samuru populasyonlarındaki azalma, su kirliliği, poliklorinat bifenil (PCB) konsantrasyonları, besin yetersizliği, kıyısal habitatın tahribi, kaçak avcılık, trafik kazaları ve balık tuzaklarına bağlı ölümler gibi çok çeşitli faktörlere bağlıdır [28]. Ancak bazı ülkelerde gerçekleştirilen yeniden kolonize edilme çalışmaları ile su samuru sayısında artış sağlanmış ve başarılı sonuçlar alınmıştır [29]. Dünyanın pek çok ülkesinde 1900'lü yıllardan beri sıkı kanunlarla korunsalar da, İrlanda'da köpek eğitimi, Arnavutluk gibi bazı ülkelerde kürkü için, Finlandiya, Macaristan, Norveç, Polonya gibi ülkelerde de balık yetiştiricileri tarafından zaman zaman avlanılmasına izin verilmektedir [21]. Ülkemizde ise su samuru, 1/7/2003 tarihli ve 4915 sayılı Kara Avc1lığı Kanununun 2 ve 4. maddelerine dayanılarak Orman ve $\mathrm{Su}$ İşleri Bakanlığınca koruma altına alınan yaban hayvanları arasındadır [10]. Su samurları firsatçı hayvanlardır. Böcek, balık, kurbağa, kuş, küçük sürüngenler, küçük memeli hayvanlar, tatlı su mid- 
yeleri ve meyve gibi geniş bir yelpazede beslenme listesine sahiptirler [25]. Ancak, besin sinırlamas1 yaşadıkları bölgedeki çeşitlilikle doğrudan ilişkilidir. Bu durum somon balıkları ve su samuru ilişkisini inceleyen bir çalışmada ele alınmıştır [28]. Çalışma sonuçları somon balık seviyelerindeki artış ya da azalışın su samuru diyetini etkilemediğini ve beslenmede somon balığı dışındaki balıkların da tercih edilebildiğini göstermiştir. Çalışma bölgesindeki nehir ve göl sistemleri arasında belirgin bir ayrımın olmaması nedeniyle, gölde yaşayan yılan balıklarının da tüketildiği gözlenmiştir. Su samurlarının beslenme alışkanlıkları temiz su kaynaklarının istilacı türlerce biyolojik invazyonu sonucu oldukça değişmiştir. Bazı ülkelerde belirli bölgelerde sınırlı yayılış gösterirken, beslenme alışkanlıklarına göre yayılış alanları sınır tanımamaktadır [28]. Su samuru populasyon yoğunluğu ve biyolojik/ekolojik karakteri hakkında Türkiye'de [10] ve pek çok Avrupa ülkesinde $[25,28,29]$ çalışmalar yapılmıştır. Su samuru populasyonlarının izlenmesi oldukça zordur. Pek çok bölgede insan yaşantısından uzak ve ürkek bir hayat sürmektedirler. Bu nedenle gerek ülkemizde gerekse diğer ülkelerdeki verilerin populasyon yoğunluğunu ve ülkedeki dağılımını net olarak ortaya koymaması doğaldır [34].

Tablo 1. Lutra lutra'nın alt türleri [21]

\begin{tabular}{lc}
\hline Alt tür ismi & Dağılımı \\
\hline L. lutra & Yaygın \\
L. aurobrunnea & Nepal \\
L. barang & Tayland, Vietnam, Malezya, \\
L. chinensis & Sumatra, Java \\
L. kutab & Çin \\
L. meridionalis & Kaşmir \\
L. monticola & İran, Güney Rusya \\
L. nair & Nepal, Sikkim, Assam \\
L. seistanica & Sri Lanka, Güney Hindistan \\
L. whiteleyi & Afganistan, Rusya, Pamir \\
\hline
\end{tabular}

Su samurlarının doğadaki yayılışını izlemede dışk1, ayak veya belirleyici iz ve işaretlerin incelenmesi kullanılmaktadır. Demografik ve yaşam hikayeleri hakkında detaylı bilgi edinmek için genetik metotlardan da yararlanılmaktadır. Dışkıdan DNA analizi ile bireysel moleküler isimlendirme, kullanılabilecek metotlar arasında gösterilmektedir. Dışkıdan DNA ekstraksiyon şansını arttırmak için top- lanan dışkıların taze olmasını sağlamak adına gün doğumunda ve tekrarlayan günlerde örnek alınması gerekmektedir. Taze dışkı aynı zamanda fekal mikrofloranın mikroskobik ve makroskobik karakteri hakkında da sağlıklı bilgiler vermektedir [29].

Memeli hayvanlarda bağırsak mikroflorası beslenme alışkanlığı ve besin kaynağına göre değișkenlik gösterse de, su samurlarında beslenme ile mikroflora arasında ilişki olmadığ 1 bildirilmektedir. Su samuru fekal mikroflorası ve potansiyel patojenlerin identifikasyonu, su samuru populasyon sağlığı öneminin anlaşılması ve izlenmesi açısından oldukça önemlidir. Su samurlarının mikroflorasını belirlemek için yapılan bir çalışmada [25], 31 adet dışkı örneği aerobik, anaerobik sporlu bakteri izolasyonu ve PCR ile viruslar (Coronavirus, Parvovirus, Adenovirus, Parainfluenza virus) yönünden incelenmiştir. Araştırma sonuçları su samurlarının mikroflorasında çok farklı bakteri olduğunu göstermiştir. 88 adet Gram negatif (23 sinıf) ve 44 adet Gram negatif (10 sınıf) bakteri izole edilmiştir. Dört izolat kesin olarak identifiye edilememiş ve hayvan izolatları ile ilgili biyokimyasal testlerin optimizasyonu sonucu 16S rRNA sekansı gerçekleştirilmiştir (Tablo 2 ve 3). Hiçbir örnekte incelenen virus tipleri tespit edilememiştir. Araştırıcılar, farklı örnekleme alanlarından daha fazla hayvandan sağlanan kapsamlı verilerle fekal flora ve geçici bakterilerin ayırt edilebileceğine işaret etmişlerdir.

Evcil hayvanlar ve insanlar birçok benzer patojeni paylaşırlar. Evcil veya yabani hayvan orijinli ve insanlarda hastalığa neden olan patojenler zoonotik organizmalar olarak bilinmektedir [2]. İnsanları etkileyen hastalıkların yaklaşı \% \%61'i zoonoz karakterde olduğu için dünya çapında yaygın bir insan sağlığ1 sorunudur. İnsanlardan hayvanlara geçen hastalıklar antropozoonoz hastalıklar olarak isimlendirilmektedir. Global insan populasyonundaki artışa paralel olarak antropozoonoz oranlarında belirgin bir artış görülmektedir. Bazı insan hastalıkları yaban hayatının korunması ile doğrudan bağlantılidır. Evcil hayvan patojenlerinin çoğu $(\% 77)$ ve evcil etçil hayvan patojenlerinin daha fazlası (\%91) yaban hayatı dahil pek çok konakçıyı enfekte edebilmektedir. Bu grup patojenleri tanımlamak, insan ve evcil hayvanlarda yeni enfeksiyonların ortaya çıkışını önlemek adına insan sağlığı açısından çok önemlidir [6]. 
Tablo 2. Su samuru dışkı örneklerinden izole edilen Gram pozitif bakteriler [25]

\begin{tabular}{lccc}
\hline Sinıf & \multicolumn{1}{c}{ Tür } & $\begin{array}{c}\text { İzolat sayısı } \\
(\%)\end{array}$ & $\begin{array}{c}\text { Pozitif örnek } \\
\text { sayıs }\end{array}$ \\
\hline Aerococcus & A. viridans & $2(1.5)$ & 2 \\
Bacillus & B. brevis, B. cereus, B. licheniformis, B. megaterium, & $12(9.1)$ & 8 \\
Cellulomonas/ & B. pumilus, B. sphaericus, Bacillus sp. & $2(1.5)$ & 2 \\
Microbacterium & Cellulomonas/Microbacterium sp. & $12(9.1)$ & 10 \\
Clostridium & C. beijerinckii/butyricum, C. perfringens, & $3(2.3)$ & 2 \\
Corynebacterium & C. sordelii, Clostridium sp. & $5(3.8)$ & 5 \\
Enterococcus & C. aquaticum, C. diphteriae mitis & $1(0.8)$ & 1 \\
Paenibacillus & E. durans, E. faecalis, E. faecium & $3(2.3)$ & 3 \\
Propionibacterium & P. alvei & $1(0.8)$ & 2 \\
Staphylococcus & P. avidum & $1(0.8)$ & 1 \\
Streptococcus & S. simulans & $2(1.5)$ & 2 \\
İsimlendirilmeyen & S. porcinus & $44(33.3)$ & \\
Toplam & & & \\
\hline
\end{tabular}

Tablo 3. Su samuru dışkı örneklerinden izole edilen Gram negatif bakteriler [25]

\begin{tabular}{|c|c|c|c|}
\hline Sinıf & Tür & $\begin{array}{c}\text { İzolat sayısı } \\
(\%)\end{array}$ & $\begin{array}{c}\text { Pozitif örnek } \\
\text { sayısı }\end{array}$ \\
\hline Acinetobacter & A. lwoffi & $1(0.8)$ & 1 \\
\hline Aeromonas & A. hydrophila, A. hydrophila/caviae, A. sobria & $18(13.6)$ & 15 \\
\hline Agrobacterium & A. tumefaciens & $1(0.8)$ & 1 \\
\hline Burkholderia & B. cepacia & $4(3.0)$ & 4 \\
\hline Buttiauxella & B. agrestis & $1(0.8)$ & 1 \\
\hline Chryseomonas & C. luteola & $1(0.8)$ & 1 \\
\hline Citrobacter & C. amalonaticus, C. braaki, C. youngae, Citrobacter sp. & $7(5.3)$ & 6 \\
\hline Empedobacter & E. brevis & $1(0.8)$ & 1 \\
\hline Enterobacter & $\begin{array}{c}\text { E. amnigenus, E. cancerogenus, E. cloacae, E. gergoviae, } \\
\text { E. sakazakii, Enterobacter sp. }\end{array}$ & $7(5.3)$ & 7 \\
\hline Escherichia & E. coli, E. vulneris & $3(2.3)$ & 3 \\
\hline Hafnia & H. alvei & $2(1.5)$ & 2 \\
\hline Klebsiella & K. oxytoca, K. pneumoniae, $K$. ozaenae & $3(2.3)$ & 3 \\
\hline Moraxella & Moraxella sp. & $2(1.5)$ & 2 \\
\hline Morganella & M. morganii & $1(0.8)$ & 1 \\
\hline Pantoea & P. agglomerans, Pantoea spp. & $13(9.8)$ & 12 \\
\hline Pasteurella & Pasteurella sp. & $1(0.8)$ & 1 \\
\hline Pseudomonas & P. aeruginosa, $P$. fluorescens, $P$. putida & $5(3.8)$ & 5 \\
\hline Rahnella & R. aquatilis & $1(0.8)$ & 1 \\
\hline Salmonella & S. arizonae, S. pullorum & $4(3.0)$ & 3 \\
\hline Serratia & S. fonticola, S. plymuthica, Serratia sp. & $3(2.3)$ & 2 \\
\hline Shigella & Shigella sp. & $1(0.8)$ & 1 \\
\hline Vibrio & V. alginolyticus, $V$. metschikovii, V. parahaemolyticus & $5(3.8)$ & 5 \\
\hline Yokenella & Y. regensburgei & $1(0.8)$ & 1 \\
\hline İsimlendirilmeyen & & $2(1.5)$ & 2 \\
\hline Toplam & & $88(66.7)$ & \\
\hline
\end{tabular}


Yaban hayatı ve evcil hayvanların paylaştıkları hastalıklar açısından hastalık ekolojisini etkileyen faktörleri araştırmak gerekmektedir. Şüphesiz hayvan yetiştiriciliği ve yaban hayatı arasında bağlantı kuran çiftlikler, tarım alanları ve demografik değişimler ve hayvan hareketleri hastalıkların yayılışında önemli rol oynamaktadır. Su samurları zaman zaman yerleşim merkezlerine gelerek, insanlarla doğrudan temas kurabilmektedir [28].

$\mathrm{Su}$ samurlarında geçerli mikroflora karakterizasyon çalışmaları yetersizdir, dışk1 izolatlarının klinik önemi ve çevresel kontaminant ilişkili hastalıklar hakkında az sayıda bilgi mevcuttur. Su samurları viral, bakteriyel, mantar ve paraziter hastalıklardan etkilenebilmektedir [29].

\section{Su Samuru Hastalıkları}

\section{Bakteriyel Hastalıklar}

Tüberküloz: Tüberküloz, çok bulaşıcı ve kronik seyrettiği için, su samurları açısından en önemli hastal1ktır. Hastalık, Mycobacterium tuberculosis, $M$. bovis veya $M$. avium tarafından oluşturulmaktadır. Çoğu Avrupa ülkesinde sığır tüberkülozu eradike edilmişken ve $M$. humanus ve $M$. microti çok nadir izole edilirken, $M$. avium nedenli vakalar bildirilmektedir. Hastalık tüberkülozlu kanatlıların tüketilmesiyle meydana gelmektedir [21].

M. tuberculosis enfeksiyonu egzotik etçil hayvanlarda çok nadiren rapor edilmektedir. Avrupa'da hayvanat bahçesinden getirilen bir su samurunda tüberküloz vaka takdimi yapılmıştır [16]. Su samurlarında ilk doğrulanmış $M$. bovis enfeksiyonu Lee ve ark. [15] tarafindan yapılmıştır. Önceki yıllarda da tüberküloz bildirimi yapılmıştır. Ancak, mikobakteriyel enfeksiyon bakteriyolojik kültür ve moleküler metotlarla doğrulanmamıştır [5]. Çeşitli mantar sporlarının solunması sonucu görülen akciğer granulomatöz lezyonları, tüberküloz lezyonlar1na benzerlik gösterdiği için $M$. bovis izolasyonu ve doğrulanması yapılmalıdır [19].

Kuzey İrlanda'da 2008 y1lı Ocak ayında ölü olarak bulunan yetişkin bir erkek su samuru postportem incelenmiştir. Karaciğer, akciğer, dalak ve ince barsak örnekleri histolojik olarak incelenmiş ve Ziehl-Neelsen (ZN) yöntemiyle boyanmıştır. Akciğer örneklerinde kapsüllenmemiş makrofaj ve lenfosit yığınlarından oluşan fibrinoid nekroz odak- ları belirlenmiștir. ZN boyamada akciğer ve böbrek lezyonlarındaki makrofajlar içinde çok sayıda aside dirençli basiller saptanmıştır Böylece $M$. bovis' in su samurlarında enfeksiyon yapabildiği gösterilmiştir. Örneklerden izole edilen ve moleküler olarak da karakterize edilen $M$. bovis alt tipi sığırlarda tüberküloz vakalarından izole edilen suşlarla yakından ilişkili bulunmuştur. $\mathrm{Bu}$ nedenle, su samurlarının enfeksiyonu direkt veya indirekt olarak sığırlardan ya da aynı etkenle enfekte olduğu bilinen porsuk (Meles meles) gibi ortak bir yabani kaynaktan alabileceğine işaret edilmektedir [15].

İngiltere'de gerçekleştirilen bir araştırmada, çoğunluğu trafik kazaları (\%80) ve daha azı septik 1sırık yaralanmaları (\%10) sonucu ölmüş 690 su samuru incelenmiştir. Nekropsi sonucunda tüberküloz şüpheli lezyonlar histolojik ve doku örnekleri de kültürel yöntemlerle analiz edilmiştir [36]. Ayrıca 2000 yılı boyunca 18 su samuruna ait akciğer ve lenf düğümleri mikobakteriler yönünden kültüre edilmiştir [35]. Her iki çalışmada da organlarda makroskobik olarak tüberküloz lezyonları izlenmemiş ve incelenen tüm örnekler mikobakteriler aç1sından histolojik ve kültürel yönden negatif bulunmuştur $[35,36]$.

Çek Cumhuriyetinde 2002-2007 yılları arasında gerçekleştirilen bir çalışmada [13] incelenen 4 su samurunun tamamı M. avium subsp. paratuberculosis yönünden negatif bulunmuştur. Benzer şekilde, İspanya'da yabani karnivorlarda gerçekleştirilen retrospektif bir araştırmada [20] farklı türlerden alınan kan serumları M. bovis proteinine (MPB70) karş1 antikor yönünden incelenmiş ve örnek alınan su samuru ELISA ile serolojik olarak negatif bulunmuştur.

Salmonella Enfeksiyonları: Salmonella türleri insan, evcil ve yabani hayvanları etkileyen önemli zoonotik enteropatojenlerdir. İnsan ve yaban hayatındaki hayvanlardan benzer türlerin izole edilmesi, Salmonella türleri için yabani hayvanların birer rezervuar olabileceğini göstermiştir. Hayvanlar etkeni asemptomatik olarak taşıyabilirler ve aralıklı olarak yayabilirler. Hayvanlarda enteritis, septisemi ve abort gelişebilir. Etkenler çevrede çok uzun süre canlı kalabildiği için, fekal-oral yolla veya kontamine su ya da gida ile bulaşabilmektedir. Su samurları, Salmonella türlerini kontamine su, gida, hayvansal atıklar veya yabani kuşlardan alabilmektedir [26]. 
Koruma alanlarındaki rehabilitasyon merkezinde [3] ve yabani hayatta [11] su samurlarından Salmonella türleri izole edilmiştir. Su samurlarında Salmonella anatum'un böbrek hasarı oluşturduğu bildirilmiştir [8]. Portekiz'de yapılan bir çalışmada [26] incelenen 67 su samuru dışkı örneğinin 5'inde (\%7.6) Salmonella izolasyonu yapılmıştır. İzolatların 3'ü S. enterica ssp. arizonae, 2'si de S. Gallinarum olarak identifiye edilmiştir. Araştırmada izolatların tamamı amoksisilin-klavulonik asit, ampisilin, sefhaleksin ve penisiline dirençli bulunmuştur. Çoklu antibiyotik dirençliliğine sahip Salmonella türleri açısından su samurlarının taşıyıcı olabileceğine vurgu yapılmıştır. Su samurlarında doğal yaşam alanlarında antibiyotik tedavisi görmedikleri halde, antibiyotik dirençli bakterilerin izole edilmesi dirençliliğin çevresel olarak aktarılabileceğini göstermektedir. Bu hayvanlar, evcil hayvanlarda ve insanlarda tedavi veya koruyucu amaçla kullanılan antibiyotiklerle yaşam alanlarında karşı karşıya kalabilmektedirler [29].

Enterokok Enfeksiyonları: Enterokoklar pek çok hayvan türünde olduğu gibi, su samurlarının da bağırsak mikroflorasını oluşturan bakterilerdir. Portekiz'de gerçekleştirilen bir çalışmada [31] su samurlarına ait dışkı örneklerinden, konvansiyonel/ moleküler metotlarla izole edilen 29 Enterokok suşu virülens faktör ve antibiyotik dirençliliği açısından incelenmiştir. İzolatların 19'u E. faecalis, 9'u E. faecium ve 1'i de $E$. durans olarak isimlendirilmiş ve PCR-fingerprinting sonucu yüksek düzeyde genomik çeşitlilik saptanmıştır. İzolatların 3'ünde sitolizin ve 6'sında jelatinaz belirlenmiştir. İzolatların 5'i ace ve $a c m$, 7'si ebpABC, 14'ü gelE ve 3'ü de cylA genleri açısından pozitif bulunmuştur. Tüm izolatlarda antibiyotik dirençlilik saptanmıştır. 17 izolatta tet(M) ve $p b p 5,13$ izolatta $v a n B$ ve 5 izolatta $v a n D$ direnç geni tespit edilmiştir. Tüm gentamisin dirençli enterokok suşlarında gentamisin dirençliliğgini kodlayan aac(60)-Ieaph(200) geni saptanmıştır. Tüm izolatlar virülens ve/veya antibiyotik direnç özelliklerine sahip oldukları için, serbest yaşayan su samurlarının virülent/dirençli enterokokların aynı ekolojik alanı paylaşan diğer hayvanlar arasında yayılışındaki ve direkt olarak etkileşim halinde oldukları insanlar açısından potansiyel sağlik riski oluşturmasındaki rolleri göz ardı edilmemelidir. Antibiyotik dirençliliğinin düşük seviyelerde olma-
S1, örnek toplanan hayvanların önceleri antibiyotik tedavisi görmemesi nedeniyle beklenen bir sonuç olarak yorumlanmıştır. Bununla birlikte, su samuru orijinli 5 izolatın vankomisine ve 11 izolatın da gentamisine dirençli olması özellikle bu antibiyotiklerin klinik öneminden dolayı dikkat çekicidir. Tüm izolatlar amoksisilin+klavulanat ve ampisiline duyarlı bulunmuştur. Diğer yandan, gentamisin insanlarda yaygın bir şekilde enterokokal enfeksiyonların tedavisinde kullanıldığı için bu direncin ortaya çıkması ve yayılışı insan sağlığı açısından risk teşkil edebilmektedir [31].

Stafilokok Enfeksiyonları: Stafilokoklar su samurlarında apse olgularında izole edilmiştir [8]. Ayrıca, stafilokoklarla ilişkili hepatik hematom, akciğer, böbrek, dalak ve subkutanöz apseleri içeren sekonder enfeksiyonlar bildirilmiştir [11]. Başka bir çalışma Avusturya yaban hayatında oksasilin dirençli Stafilokok türlerinin belirlenmesi amaciyla 2012-2013 yılları arasında gerçekleştirilmiştir. 40 farkl1 yaban hayvanına ait burun ve perineal svap örneği incelenmiş ve bir su samurundan $S$. aureus izolasyonu yapılmıştır. Hayvanda makroskobik olarak şiddetli purulent pnömoni ve leptomeningitis tespit edilmiştir. Böylece, su samurlarından ilk kez mecC geni pozitif MRSA saptanmıştır [17].

Yersinia Enfeksiyonları: Yersinia enterocolitica ve $Y$. pseudotuberculosis insanlar için önemli enterik patojen etkenler arasında yer almaktadır. Enfektif insan suşları kontamine gıda, enfekte hayvanlarla temas ve kişiden kişiye temas ile bulaşabilmektedir. Yabani hayvanlar Yersinia türlerinin bulaştırılmasında önemli bir potansiyel araç olarak görülmektedir. Su samurlarının, yersiniozisin epidemiyolojisinde önemli rol oynayan $Y$. enterocolitica ve $Y$. pseudotuberculosis bakımından muhtemel doğal rezervuar olduğu gösterilmiştir. Patojenik Yersinia türleri, su samurlarının da içinde olduğu 37 farklı yabani hayvan türünde incelenmiş ve $3 \mathrm{su}$ samuruna ait akciğer örneğinin 1 'inden $Y$. pseudotuberculosis serotip O:2 izole edilmiştir [24].

Klostridiyal Enfeksiyonlar: İskoçya'da rehabilitasyon merkezinde, ölü bir su samuruna ait doku örneklerinde Clostridium piliforme izole ve identifiye edilmiştir. Genellikle laboratuvar hayvanlarında Tyzzer hastalığına neden olan etken, ilk kez su samurlarında bildirilmiştir [35]. Su samurlarında toksijenik $C$. perfringens' in varllğ 1 Kimber ve Kollias 
[11] tarafından bildirilmiștir. Ayrıca gazlı kangren etkenlerinden $C$. welchii, su samurlarından izole edilmiştir [21].

Leptospirozis: Leptospirozis, hayvanlardan insanlara bulaşan zoonoz bir hastalıktır. Hastalık, belirti göstermeyen taşıyıcı kemirgenler, vahşi hayvanlar, çiftlik ve evcil hayvanların idrarları ile kirletilmiş gida ve sular ile bulaşabilmektedir [9]. İnkübasyon periyodu 2 gün-3 ay arasında değişmektedir. Su samurlarında Leptospira enfeksiyonu nadiren rapor edilmekle birlikte, inaktif aşılama ve yıllık tekrarı önerilmektedir [21]. Farklı türlerden 201 yabani ve evcil etçil hayvan üzerinde yapılan bir araştırmada [22] serum, idrar ve böbrek örnekleri leptospirozis açısından incelenmiştir. Su samurları hariç tüm hayvanların etkenle temas ettikleri bildirilmiştir.

Diğer Bakteriyel İnfeksiyonlar: Su samurlarında Proteus mirabilis kökenli ürogenital sistem enfeksiyonları bildirilmiştir $[3,8]$. Böyle enfeksiyonlar genellikle Streptokok enfeksiyonları ve Kolibasillozis ile ilişkilendirilmiştir [21].

Acinetobacter ve Pasteurella türlerinin su samurlarındaki potansiyel patojenik rolleri hakkındaki literatür verileri sınırlıdır. Kimber ve Kollias [11] Acinetobacter türlerini su samurlarında tanımlamışlar, ancak klinik önemi hakkında bilgi vermemişlerdir. Fransa'da su samuru rehabilitasyon merkezinde yapılan bir araştırmada [4], 1sırık ve çeşitli nedenlerle yaralanan su samurlarında yüksek oranda (\%62.5) ölümlerin görüldügü bildirilmiştir. İncelenen örneklerin ikisinden Pasteurella multoci$d a$ izole edilmiştir.

Klebsiella pneumoniae kökenli retrofarengial apse ve ağır pnömoni olguları sonrası su samurlarında ölümler olduğu bildirilmiştir. Ayrıca araştırıcılar, patojenik E. coli nedenli ürogenital sistem enfeksiyonlarından bahsetmişler ve beta-hemolitik streptokoklarla ilişkili ürogenital sistem enfeksiyonlarına dikkat çekmişlerdir [8].

Pseudomonas türlerinin potansiyel patojenik rolleri araştırılmış, sadece $P$. putrefaciens ile ilişkili su samuru hastalıkları belirlenmiştir [11].

İngiltere'de trafik kazası sonucu ölmüş su samurundan izole edilen Gram pozitif katalaz negatif kok morfolojisine sahip bir bakterinin isimlendirilmesi fenotipik ve filogenetik incelemelerle araşt1rılmıştır. Karşılaştırmalı 16S rRNA gen sekansı so- nucunda bu bakteri Vagococcus sinifi ile yakından ilişkili, ancak Vagococcus fluvialis ve $V$. salmoninarum'dan farkl1, yeni bir alt tür olarak tanımlanmıştır. Bilinmeyen bu bakteri, biyokimyasal testler ve tüm hücre proteinlerinin elektroforetik analizleri ile iki Vagococcus türünden ayrılmıştır. Filogenetik ve fenotipik esaslara göre bu yeni tür $V$. lutrae olarak isimlendirilmiştir [14].

Plesiomonas shigelloides tarafindan şekillendirilen su samuru abort vakası bildirilmiştir [21].

\section{Viral Hastalıklar}

Su samurlarında bazı köpek ve kedi viral patojenlerine karşı duyarlılık belirlenmiştir. Köpek ve kedi parvoviruslar1, coronovirusları, köpek herpes virusları ve köpek adenovirus tip 2'ye karş1 antikorların varlığından söz edilmesine rağmen [11,12], su samurlarının virusların yayılmasında rezervuar olarak potansiyel rolleri yeterince net değildir [21].

Su samurlarına ait dişkı örneklerinin Adenovirus, Parvovirus, Parainfluenza virus yönünden PCR ile analiz edildiği bir çalışmada [25] tüm örnekler negatif bulunmuştur. Araştırmada, örnek alınma zamanına dikkat çekilerek doğru örnekleme yapmak için farklı sezonlarda örnek alınması gerekliliğine vurgu yapılmıştır.

Diğer yandan Kore Cumhuriyeti'nde gerçekleştirilen bir araştırmada, ölü olarak bulunan bir su samurunda Canin adenovirus tip 1 (CAV-1) tespit edilmiştir. Nekropside karaciğerde büyüme ve nekroz, böbrekte atrofi belirlenmiştir. Mikroskopik olarak plazma hücreleri ve lenfositlerden oluşan mononükleer hücre infiltrasyonu ile multifokal karaciğer nekrozu saptanmıştır. Karaciğerde, elektron mikroskobu ile hepatositlerin çekirdeğinde karakteristik, $70 \mathrm{~nm}$ çapında, adenovirus partikülleri görülmüştür. Araştırıcılar, CAV-1 için su samurlarında ilk tespit olduğuna dikkat çekmişlerdir. Ayrıca, hayvanın etkene karşı aşılanmadığını, su samurları için hastalığın ölümcül olabileceğini bu nedenle inaktif bir aş1 ile aşılama yapılması, ek olarak diğer etçil hayvanlarla temasın önlenmesi için etkili hijyenik tedbirlerin alınması gerekliliğine işaret etmişlerdir [27].

Kuduz: Avustralya ve bazı küçük adalar d1şında dünyanın pek çok kısmında Kuduz hastalığı görülmektedir. Su samurlarında kuduz vakaları bil- 
dirilmiş [30] ve insanlar için risk oluşturduklarına dikkat çekilmiştir. Hastalığın inkübasyon süresi bir hafta ile birkaç ay arasındadır. Su samurlarında kuduza karşı inaktif aşı ile her yıl aşılama bağışıklık için önerilmektedir [21].

Köpek Gençlik Hastalığı (Distemper): $\mathrm{Su}$ samurlarında köpek gençlik hastalığ 1 virusu belirlenmiştir [7]. İnaktif bir aşı ile yıllık aşılama önerilmektedir. Ancak, inaktif aşılama yeterince uzun süre bağışıklık sağlamadığı için attenüe canlı aşıların kullanılmasının daha doğru bir yaklaşım olduğuna dikkat çekilmektedir [21].

Parvovirus Enfeksiyonu: $\mathrm{Su}$ samurlarının hastalığa duyarlı olduğu bildirilmiş, bazı su samuru türlerinde hastalığa karşı seropozitiflik saptanmış ve inaktif köpek aşıları ile yıllık aşılama tavsiye edilmiştir [21].

\section{Mantar Hastalıkları}

Su samurlarında mantar hastalıkları oldukça nadiren görülmektedir. Rapor edilen ilk mantar vakasından Monilia türü izole edilmiştir. Söz konusu mantar türünün normal deri mikroflorasında kommensal olarak bulunan firsatçı patojen olduğu belirlenmiştir. Hastalığın şekillenmesinde çevresel etkenler, kondisyon kaybı ve stres faktörleri etkili bulunmuştur. Ancak su samuru kürkünün sağlam olduğu ve mantarın yayılmadığı saptanmıştır [21].

İtalya'da gerçekleştirilen güncel bir çalışmada [17], trafik kazası sonucu ölen bir su samurundan Emmonsia türü mantar izole edilmiştir. Emmonsia türlerine ait mantarların solunması sonucu ortaya çıkan hastalık Adiaspiromikozis olarak tanımlanmaktadır. Diğer yandan, Coccidiodes immitis, Microsporum spp ve Trychophyton spp. türü mantarların su samurlarında potansiyel olarak klinik öneme sahip oldukları bildirilmektedir [6].

\section{Paraziter Hastalıklar}

Su samurları çok sayıda zoonotik potansiyele sahip parazite konakçılık etmektedir. Yarı sucul yaşayan bu hayvanlar, kara, tatlı su ve deniz habitatları arasında patojenlerin taşınmasında önemli rol üstlenmektedirler. Buna rağmen, su samurlarının taşıdığ 1 parazitler fazlaca incelenmemiştir [21].

Su samurlarında kene ve bit dışında ektoparazit bildirimi yapılmamıştır. Ektoparaziter hastalıkların dağılımı, yayılıșı ve görülme sıklığı biyolojik yaşam evrelerine bağlı olarak mevsimsel değişkenlik göstermektedir. Su samurlarında bulunan ektoparazitlerin ve bunların biyotik veya abiyotik değişkenlerden etkilenip etkilenmediğini araştırmak için yapılan bir çalışmada, incelenen hayvanlarda ektoparazit olarak sadece Ixodes hexagonus türünde kene tespit edilmiştir. İncelenen hayvanlarda başka kene türlerinin tespit edilmemesi, su samurların gece avlanması ve yarı sucul bir yaşam sürmesi ile bağlantılı olabileceği ifade edilmiştir. Kondisyonu iyi olan hayvanlarda kötü kondisyonlu olanlara göre daha az kene gözlenmiştir. Su samurlarının çok sayıda kene taşıması nedeniyle bu hayvanların I. hexogonus türü kenelerce taşınan zoonoz etkenlerin yayılmasında potansiyel rollerinin araştırılması sonucuna varılmiştır [32].

Diğer yandan, hastalıkların nakledilmesinde önemli olan, Amblyoma americanum, Dermacentor variabilis, Ixodes banisi, I. cookie ve I. uriae gibi kene türlerinin de su samurlarında tespiti yapılmış$\operatorname{tir}[6]$.

Su samurlarında sestod, nematod, trematod ve protozoon türlerini içeren, çok sayıda endoparazit türü tespit edilmiş, ancak pek çoğunun klinik ve patolojik önemi ortaya konulamamıştır. Spirometra mansonoides (sestod), Dracunculus insignis, Strongyloides lutrae, Capillaria aerophilus, Capillaria hepatica, Gnathostoma miyazakii, Dioctophyme renale (nematod) ve Paragonimus kellicoti (trematod)'nin su samurlarında hastalık yaptığ 1 bilinmektedir. Ayrica, Cryptosporidium spp., Giardia spp., Isospora spp., Sarcocystis spp. ve Toxoplasma gondii gibi protozoonlarla ilgili nadir de olsa, daha çok serolojik olmak üzere hastalık vakaları rapor edilmiştir [6]. Diğer yandan, Isthmiophora melis, Opisthorchis felineus, Eustrongylus gigas, Eryhelmis, Molineus, Heterophyidae alt türleri yaygın olarak saptanan endoparazitlerdir. I. melis ve $O$. felineus türleri zoonoz potansiyele sahiptirler. Su samurlar1nın karın boşluğunda ve pelvis renalisinde yaşayan E. gigas, böbrek doku hasarı, üreterlerde hipertrofi ve peritonitis oluşturabilen bir nematottur [21]. Genç bir su samurunun kalbinde Dirofilaria immitis belirlenmiş ve su samurlarının bu parazit için belirleyici konakçı olduğuna dikkat çekilmiştir [18].

Pseudamphistomum truncatum insanlar dahil balıkla beslenen memelileri de içeren geniş bir ko- 
nakçı spektrumuna sahip ve safrada yaşayan firsatçı trematodtur. $P$. truncatum salyangoz ve tatlı su balıkları olmak üzere iki ara konakçılı karmaşık bir yaşam döngüsüne sahiptir. Enfekte balıkların tüketilmesi ile memelilere bulaşabilen bu parazit, $249 \mathrm{su}$ samurunun 7'sinde (\%2.8) belirlenmiș ve vakaların çoğunun ölümle sonuçlandığı rapor edilmiştir [23].

Belarus'ta 18 y1llik periyotta farkl1 yabani hayvanlara ait 151 karkasin helmintolojik incelemesi amacıyla yapılan bir çalışmada [33], 25 su samuru örneğinin sadece $1(\% 4)$ 'inde Fasciola hepatica tespit edilmiştir. Araştırıcılar ortak yaşam alanlarının $F$. hepatica yumurtalarını içeren dışkıları taş1yan yabani hayvanlarca kontamine edilmesinin arakonakçı olan yumuşakçaların enfeksiyonuna neden olabileceğine ve hastalığın diğer duyarlı konakçılara bulaştırılabileceğine dikkat çekmişlerdir.

Toksoplazmozis, hem insan hem de evcil ve yabani hayvanları etkileyen, dünya çapında öneme sahip zoonotik bir hastalıktır. Dünya Sağlık Örgütü, henüz yabani/evcil hayvanlar ve insanlar arasında kesin olarak enfeksiyon bağlantısı kurulamamasına rağmen, Toxoplasma gondii hakkında detaylı epidemiyolojik verilerin toplanmasını önermektedir. Yabani hayvanlarda hastalığın seroprevalans1 yeterince çalışılmamıştır. İngiltere'de gerçekleştirilen bir araştırmada [4], çeşitli nedenlerle ölmüş $271 \mathrm{su}$ samuruna ait göğüs boşluğundaki kan örneklerinin 108 (\%39.9)'inde T. gondii'ye karş1 seropozitiflik belirlenmiștir. Çalıșmada ölüm nedenlerinin bu hastalıktan olup olmadığının net olarak bilinmediğini, ancak su samurlarında seropozitifliğin yüksek bulunmasının hastalığın epidemiyolojisi açısından önemli olduğuna vurgu yapılmıştır. İspanya'da yapılan benzer bir çalışmada [37], farklı türden 282 yabani etçil hayvan $T$. gondii açısından serolojik olarak incelenmiș ve 6 su samurunun tamamında seropozitiflik saptanmıştır.

Su samurlarında, parazitlerin önemi diğer etçil hayvanlara göre daha azdır. Sosyal temas eksikliği, düşük nüfus yoğunluğu ve genellikle büyük “ev aralığg”" parazitlerin yayılışı için ekolojik engellerdir. Özellikle dışkılama alanlarına seyrek ziyaretler ve su ile sık temas dışkı ile enfeksiyon tehlikesini sinırlamaktadır. Ayrica su, yumurta ve larva konsantrasyonunun seyreltilmesinde etkili olmaktadır. Ancak özellikle yaşam alanlarına yeni katılan hayvanlarda dışkıların parazitler açısından periyodik taranması gerekli görülmektedir. Bazı bölgelerde düzenli aşılamalara ilave olarak, endoparaziter ilaç uygulamaları önerilmektedir [21].

\section{Neoplastik Hastalıklar}

Su samurlarında neoplastik hastalıklar çok nadir görülmektedir. Ancak çeşitli ülkelerde zaman zaman bildirimi yapılmaktadır. Malignant melanom [38], hepatosellüler adenom [1] ve testis örneklerinde sertoli hücre tümörü [3] saptanmıştır.

\section{Așilama}

Su samurları bazı viral hastalıklara (Kuduz, Distemper) karşı 1900'lü yıllarda aş1lanmaktayken, günümüzde yaygın aşılamalar yapılmamaktadır. Bununla birlikte Parvoviral enteritis, Distemper, Kuduz ve Leptospirozise karşı aşılamalar önerilmektedir [6].

\section{Sonuç}

Bu makalede, su samurlarında görülen hastalıklara ait güncel literatür verileri özetlenmiştir. Su samuru populasyonu bilinçsiz pestisit kullanımı, akarsularda balık stoklarını etkileyen çeşitli düzenlemeler, barajlar, akarsu vejetasyonunun kaldırılması, orman alanlarının açılması, yol yapımı, kaçak avcılık, istilacı türlerin çoğalması, kıyı alanlarının tahrip edilmesi, evsel ve endüstriyel atıkların akarsulara bırakılması gibi nedenlerle dünyanın pek çok ülkesinde tükenme noktasına gelmiştir.

Biyolojik çeşitliliğin ve dengenin bir göstergesi olarak kabul edilen bu hayvanların eski populasyonlarına ulaşmaları adına sıkı tedbirlerin alınması gerekmektedir. Pek çok ülkede su samurlarının yayılışı ve yaşam alanlarını belirlemeye yönelik çalışmalar yapılmıştır. Geçmişte ülkemizde geniş bir yayılış alanın olduğu bilinmekle birlikte, su samurlarının dağılımı ile ilgili detaylı bilgiler yetersizdir. Ülkemizin değişik bölgelerinde yapılacak araştırmalarla su samurları hakkında önemli veriler elde edilebilecektir.

Pek çok ülkede kurulmuş ve aktif olarak faaliyet gösteren su samuru hastalık takibi ve rehabilitasyon merkezlerinin ülkemizde de kurulması gerekmektedir. Su samurlarının mikroflorası ve taşıdığ 1 hastalıklar yönünden incelenmesi, bu hayvanların taşıdığ için insan sağlı̆̆ açısından da önemlidir. 


\section{Kaynaklar}

1. Bae IH, Pakhrin B, Jee H, Shin NS, Kim DY, (2007). Hepatocellular adenoma in an Eurasian otter (Lutra lutra). J Vet Sci. 8(1), 103-105.

2. Boynukara B, Gülhan T, (2011). Kedi Zoonozları. Tabiat ve İnsan Dergisi. 45(4), 38-45.

3. Capber F, (2007). Veterinary care of Eurasian otters (Lutra lutra) at the otter breeding centre of Hunawihr (France). IUCN Otter Spec Group Bull. 24(1), 47-62.

4. Chadwick EA, Cable J, Chinchen A, Francis J, Guy E, Kean EF, Paul SC, Perkins SE, Sherrard-Smith E, Wilkinson C, Forman DW, (2013). Seroprevalence of Toxoplasma gondii in the Eurasian otter (Lutra lutra) in England and Wales. Parasite Vector. 6(75), 2-5.

5. Delahay RJ, De Leeuw AN, Barlow, AM, Clifton-Hadley RS, Cheeseman CL, (2002). The status of Mycobacterium bovis infection in UK wild mammals: a review. Vet J. 164, 90-105.

6. Gaydos JK, (2014). Diseases of river otters, a recovering species. Proceedings of the 2014 North American Veterinary Conference, Orlando, Florida. http://www.seadocsociety.org/wp-content/uploads/Diseases-of-River-Otters-J.Gaydos.pdf.

7. Geisel O, (1979). Staupe bei Fischottern (Lutra lutra). Berl Münch Tierärtl Wschr. 92(15), 304.

8. Hoover JP, Tyler RD, (1986). Renal function and fractional clearances of American river otters (Lutra canadensis). J Wildlife Dis. 22, 547-556.

9. Kanat Ö, Gülcü Y, Akpınar Y, Kesler K, Doğan M, Yüzbaşıgil F, (2014). Leptospirozis, Zoonoz Hastalıklar. Olgun-Çelik Ofset Matbaa, Konya. 5-8.

10. Karakaş MM, Albayrak İ, (2014). Bioecology of the otter (Lutra lutra) in Kizılırmak River in Kirıkkale Province. Hacettepe J Biol Chem. 42(3), 313-321.

11. Kimber KR, Kollias GV, (2000). Infectious and parasitic diseases and contaminant-related problems of North American river otters (Lontra canadensis): A review. J Zoo Wildlife Med. 31, 452-472.

12. Kimber KR, Kollias GV, Dubovi EJ, (2000). Serologic survey of selected viral agents in recently captured wild North American river otters (Lontra canadensis). J Zoo Wildlife Med. 31,168-175.

13. Kopecna M, Trcka I, Lamka J, Moravkova M, Koubek P, Heroldova M, Mrlik V, Kralova A, Pavlik I, (2008). The wildlife hosts of Mycobacterium avium subsp. paratuberculosis in the Czech Republic during the years 2002-2007. Vet Med-czech. 53(8), 420-426.

14. Lawson PA, Foster G, Falsen E, Ohlen M, Collins MD, (1999). Vagococcus lutrae sp. nov., isolated from the common otter (Lutra lutra). Int J Syst Bacteriol. 49, 1251-1254.

15. Lee J, Hanna R, Hill R, Mccormick CM, Skuce RA, (2009). Bovine tuberculosis in an Eurasian otter. Vet. Rec. 164, 727-728.

16. Lepper AWD, Corner LA, (1983). Naturally occurring mycobacterioses of animals. Ratledge C. \& Stanford J. eds.
Biology of Mycobacteria, Academic press Inc, London. p.418-444.

17. Loncaric I, Kübber-Heiss A, Posautz A, Stalder GL, Hoffmann D, Rosengarten R, Walzer C, (2013). Characterization of methicillin-resistant Staphylococcus spp. carrying the mecC gene, isolated from wildlife. J Antimicrob Chemother. 68, 2222-2225.

18. Malatesta D, Simpson VR, Fusillo R, Marcelli M, Bongiovanni L, Romanucci M, Palmieri C, Salda LD, (2014). First description of adiaspiromycosis in an Eurasian otter (Lutra lutra) in Italy. Vet Ital. 50(3), 199-202.

19. Martin-Atance P, Leon-Vizcaino L, Palomares F, Revilla E, Gonzalez-Candela M, Calzada J, Cubero-Pablo MJ, Delibes M, (2006). Antibodies to Mycobacterium bovis in wild carnivores from Donana National Park (Spain). J Wildlife Dis. 42(3), 704-708.

20. Matos AC, Figueira L, Martins MH, Loureiro F, Pinto ML, Matos M, Coelho AC, (2014). Survey of Mycobacterium avium subspecies paratuberculosis in road-killed wild carnivores in Portugal. J Zoo Wildlife Med. 45(4), 775-781.

21. Melissen A, (2000). Eurasian otter Lutra lutra. Husbandry guidelines, EEP/Studbook for Lutra lutra. The Netherland, p.1-66.

22. Millán J, Candela MG, López-Bao JV, Pereira M, Jiménez MA, León-Vizcaíno L, (2009). Leptospirosis in wild and domestic carnivores in natural areas in Andalusia, Spain. Vector-Borne Zoonot. 9(5), 549-554.

23. Neimanis A, Bäcklin BM, Roos A, Moraeus C, Ågren E, Höglund J, (2013). The biliary trematode Pseudamphistomum truncatum: an emerging parasite in Swedish wildlife? 21st NWDA Meeting at Torsö, May 30 31. Lake Vänern, Sweden.

24. Nikolova S, Tzvetkov Y, Najdenski H, Vesselinova A, (2001). Isolation of pathogenic Yersiniae from wild animals in Bulgaria. J Vet Med B. 48, 203-209.

25. Oliveira M, Sales-Luis T, Duarte A, Nunes SF, Carneiro C, Tenreiro T, Tenreiro R, Santosreis M, Tavares L, Vilela CL, (2008). First assessment of microbial diversity in faecal microflora of Eurasian otter (Lutra lutra Linnaeus, 1758) in Portugal. Eur J Wildlife Res. 54, 245-252.

26. Oliveira M, Pedroso NM, Sales-Luis T, Santos-Reis M, Tavares L, Vilela CL, (2010). Antimicrobial-resistant Salmonella isolated from Eurasian Otters (Lutra lutra Linnaeus, 1758) in Portugal. J. Wildlife Dis. 46(4), 12571261.

27. Park NY, Lee MC, Kurkure NV, Cho HS, (2007). Canine adenovirus type 1 infection of a Eurasian river otter (Lutra lutra). Vet Pathol. 44, 536-539.

28. Reid N, Thompson D, Hayden B, Marnell F, Montgomery WI, (2013). Review and quantitative meta-analysis of diet suggests the Eurasian otter (Lutra lutra) is likely to be a poor bioindicator. Ecol. Indic. 26, 5-13.

29. Romanowski J, Brzeziński M, Żmihorski M, (2013). Habitat correlates of the Eurasian otter Lutra lutra recolonizing Central Poland. Acta Theriol. 58, 149-155.

30. Rubel A, Hauser B, Baumgartner R, Isenbügfel E, (1987). Veterinärmedizinsche Prophylaxe bei der Haltung 
des Europäischen Fischotter (Lutra lutra). Int Symp Erkrankungen Zootiere. 29, 285-291.

31. Semedo-Lemsaddek T, Nobrega CS, Ribeiro T, Pedroso NM, Sales-Luis T, Lemsaddek A, Tenreiro R, Tavares L, Vilela CL, Oliveira M, (2013). Virulence traits and antibiotic resistance among enterococci isolated from Eurasian otter (Lutra lutra). Vet Microbiol. 163, 378-382.

32. Sherrard-Smith E, Chadwick E, Cable J, (2012). Abiotic and biotic factors associated with tick population dynamics on a mammalian host: Ixodes hexagonus infesting otters, Lutra lutra. PLoS ONE 7(10), e47131. doi:10.1371/journal.pone.0047131.

33. Shimalov VV, Shimalov VT, (2000). Findings of Fasciola hepatica Linnaeus, 1758 in wild animals in Belorussian Polesie. Parasitol Res. 86, 527.
34. Simpson VR, (2007). Health status of otters in southern and south west England, 1996-2003. Science Report SCO10064/SR1. Environment Agency.

35. Simpson VR, Hargreaves J, Birtles RJ, Marsden H, Williams DL, (2008). Tyzzer's disease in a Eurasian otter (Lutra lutra) in Scotland. Vet Rec. 163, 539-543.

36. Simpson V, (2009). Bovine tuberculosis in Eurasian otters. Vet Rec. 164, 789.

37. Sobrino R, Cabezon O, Millan J, Pabon M, Arnal MC, Luco DF, Gortazar C, Dubey JP, Almeria S, (2007). Seroprevalence of Toxoplasma gondii antibodies in wild carnivores from Spain. Vet Parasitol. 148, 187-192.

38. Weber H, Mecklenburg L, (2000). Malignant melanoma in a Eurasian otter (Lutra lutra). J. Zoo Wildl. Med. 31(1), 87-90. 